Article

\title{
Is the Modern American Death Penalty a Fatal Lottery? Texas as a Conservative Test
}

\section{Scott Phillips * and Alena Simon}

Department of Sociology and Criminology, University of Denver, 2000 E. Asbury Avenue, Denver, CO 80208-2948, USA; E-Mail: alenasimon09@gmail.com

* Author to whom correspondence should be addressed; E-Mail: Scott.Phillips@du.edu; Tel.: +1-303-871-205-9.

Received: 24 December 2013; in revised form: 17 January 2014 / Accepted: 20 January 2014 / Published: 22 January 2014

\begin{abstract}
In Furman v. Georgia (1972), the Supreme Court was presented with data indicating that $15 \%$ to $20 \%$ of death-eligible defendants were actually sentenced to death. Based on such a negligible death sentence rate, some Justices concluded that the imposition of death was random and capricious - a fatal lottery. Later, the Court assumed in Gregg v.
\end{abstract} Georgia (1976) that guided discretion statutes would eliminate the constitutional infirmities identified in Furman: If state legislatures narrowed the pool of death-eligible defendants to the "worst of the worst" then most would be sentenced to death, eliminating numerical arbitrariness. However, recent research suggests that numerical arbitrariness remains, as the death sentence rate falls below the Furman threshold in California (11\%), Connecticut (4\%), and Colorado (less than 1\%). The current research estimates the death sentence rate in Texas. Interestingly, Texas provides a conservative test. In contrast to most states, the Texas statute does not include broad aggravators that substantially enlarge the pool of death-eligible defendants and therefore depress the death sentence rate. Nonetheless, the death sentence rate in Texas during the period from 2006 to 2010 ranges from $3 \%$ to $6 \%$ (depending on assumptions made about the data). The same pattern holds true in the key counties that send the largest number of defendants to death row: Harris (Houston), Dallas (Dallas), Tarrant (Fort Worth and Arlington), and Bexar (San Antonio). Thus, the data suggest that Texas can be added to the list of states in which capital punishment is unconstitutional as administered. If the death sentence rate in Texas runs afoul of the Furman principle then the prognosis for other states is not encouraging. 
Keywords: Arbitrariness; death penalty; death sentence rate; Texas; Furman; Gregg

\section{Introduction}

In Furman v. Georgia (1972) [1], the United States Supreme Court ruled in a 5-4 decision that the death penalty was unconstitutional as currently administered because the arbitrary imposition of death violated the 8th and 14th amendments. ${ }^{1}$ For Justices Douglas ${ }^{2}$ and Marshall ${ }^{3}$ the meaning of arbitrariness was social—race and class influenced death sentencing. For Justices Stewart, Brennan, and White the meaning of arbitrariness was numerical-the proportion of death-eligible defendants who were actually sentenced to death was so negligible that the ultimate state sanction had become random and capricious. In the famous words of Justice Stewart:

These death sentences are cruel and unusual in the same way that being struck by lightning is cruel and unusual. For of all the people convicted of rapes and murders in 1967 and 1968, many just as reprehensible as these, the petitioners are among a capriciously selected random handful upon whom the sentence of death has in fact been imposed...the 8th and 14th amendments cannot tolerate the infliction of a sentence of death under legal systems that permit this unique penalty to be so wantonly and so freakishly imposed ([1], pp. 309-10).

\section{Justice Brennan added:}

When the punishment of death is inflicted in a trivial number of the cases in which it is legally available, the conclusion is virtually inescapable that it is being inflicted arbitrarily. Indeed, it smacks of little more than a lottery system ([1], p. 293).

\section{Justice White concurred:}

The conclusion, as I have said, is that the death penalty is exacted with great infrequency even for the most atrocious crimes and that there is no meaningful basis for distinguishing the few cases in which it is imposed from the many cases in which it is not ([1], p. 313). ${ }^{4}$

1 Given that Furman was a plurality opinion, arbitrariness can only be interpreted as the holding of the Court under Marks v. United States [2].

2 Justice Douglas: “A law that stated that anyone making more than \$ 50,000 would be exempt from the death penalty would plainly fall, as would a law that in terms said that blacks, those who never went beyond the fifth grade in school, those who made less than $\$ 3,000$ a year, or those who were unpopular or unstable should be the only people executed. A law which in the overall view reaches that result in practice has no more sanctity than a law which in terms provides the same. Thus, these discretionary statutes are unconstitutional in their operation. They are pregnant with discrimination and discrimination is an ingredient not compatible with the idea of equal protection of the laws that is implicit in the ban on 'cruel and unusual' punishments” ([1], pp. 256-57).

3 Justice Marshall: "Regarding discrimination, it has been said that it is usually the poor, the illiterate, the underprivileged, the member of the minority group - the man who, because he is without means, and is defended by a court-appointed attorney-who becomes society's sacrificial lamb.' Indeed, a look at the bare statistics regarding executions is enough to betray much of the discrimination” ([1], p. 364).

4 Beyond noting the inability to meaningfully distinguish between defendants sentenced to life and death, Justice White argued that the rare imposition of death undercuts deterrence: "Most important, a major goal of the criminal law-to 
Although Furman invalidated existing state and federal statutes and commuted more than 600 death row inmates to life in prison, it did not mark the end of capital punishment. Indeed, 35 states reinstated the death penalty between 1972 and 1976. Some states attempted to eliminate arbitrariness by making the death penalty mandatory for defendants convicted of particular crimes. Other states adopted "guided discretion", an approach that: (1) narrowed and specified the range of crimes eligible for death (by delineating the statutory aggravators that elevated the seriousness of the offense); (2) bifurcated the guilt and punishment phases of a capital trial (so the rules of evidence could be relaxed in the punishment phase, allowing the prosecution and defense to present more information to jurors regarding aggravating and mitigating circumstances); and (3) guaranteed automatic appellate review of death sentences. In Woodson v. North Carolina (1976) and the companion case of Roberts v. Louisiana (1976), the Supreme Court struck down mandatory death statutes on a 5-4 vote arguing that the protection of human dignity required individual consideration of each case [3,4]. But the Supreme Court upheld guided discretion statutes on a 7-2 vote in Gregg v. Georgia (1976) and the companion cases of Proffitt v. Florida (1976) and Jurek v. Texas (1976) [5-7] (for a review see [8], pp. 89-108).

In Gregg, the Court assumed that guided discretion would solve the problem of arbitrariness identified in Furman. The Court's logic was straightforward: if state legislatures narrowed the range of offenses that were eligible for death through the specification of aggravating circumstances then the pool of death-eligible defendants would be restricted to "the worst of the worst"; if the pool of death-eligible defendants was restricted to "the worst of the worst" then most would be sentenced to death, thus eliminating social and numerical arbitrariness. Justice White articulated the prediction in Gregg:

The Georgia Legislature has plainly made an effort to guide the jury in the exercise of its discretion, while at the same time permitting the jury to dispense mercy on the basis of factors too intangible to write into a statute, and I cannot accept the naked assertion that the effort is bound to fail. As the types of murders for which the death penalty may be imposed become more narrowly defined and are limited to those which are particularly serious or for which the death penalty is peculiarly appropriate as they are in Georgia by reason of the aggravating-circumstance requirement, it becomes reasonable to expect that juries-even given discretion not to impose the death penalty-will impose the death penalty in a substantial portion of the cases so defined. If they do, it can no longer be said that the penalty is being imposed wantonly and freakishly or so infrequently that it loses its usefulness as a sentencing device. There is, therefore, reason to expect that Georgia's current system would escape the infirmities which invalidated its previous system under Furman ([5], p. 222).

The opposite occurred: the range of death-eligible offenses has consistently expanded since the time of Gregg, but the number of defendants who are actually sentenced to death has plummeted in recent decades ([9], pp. 223-24). As Kirchmeier [10,11] documents, state legislators have been unable to resist the political temptation to widen the net—an increasingly broad array of offenses have become death-eligible as states repeatedly add new statutory aggravators, expand existing statutory aggravators, or expand the definition of capital murder (see also [12]). Simon and Spaulding quip that aggravators have been added to statutes "like Christmas tree ornaments" ([13], p. 82). Even more 
consequential than the number of aggravators is the breadth of aggravators. In some states, a defendant is eligible for death if he/she commits a murder that fits one or more of the following broad aggravators: the murder was heinous, atrocious, or cruel; the murder created a grave risk of death to someone other than the victim; the defendant committed a prior violent felony; the defendant was under correctional supervision at the time of the murder (including probation or parole); the defendant committed the murder after "lying in wait;" or the murder was premeditated ([10], pp. 400-30). ${ }^{5}$ Despite the expanding number and scope of statutory aggravators, fewer defendants are being sentenced to death. ${ }^{6}$ As Figure 1 demonstrates, the annual number of death sentences in the United States has steadily declined from a peak of 315 in 1996 to a low of 78 in 2012 [15].

Figure 1. Death Sentences in the United States, 1977-2012.

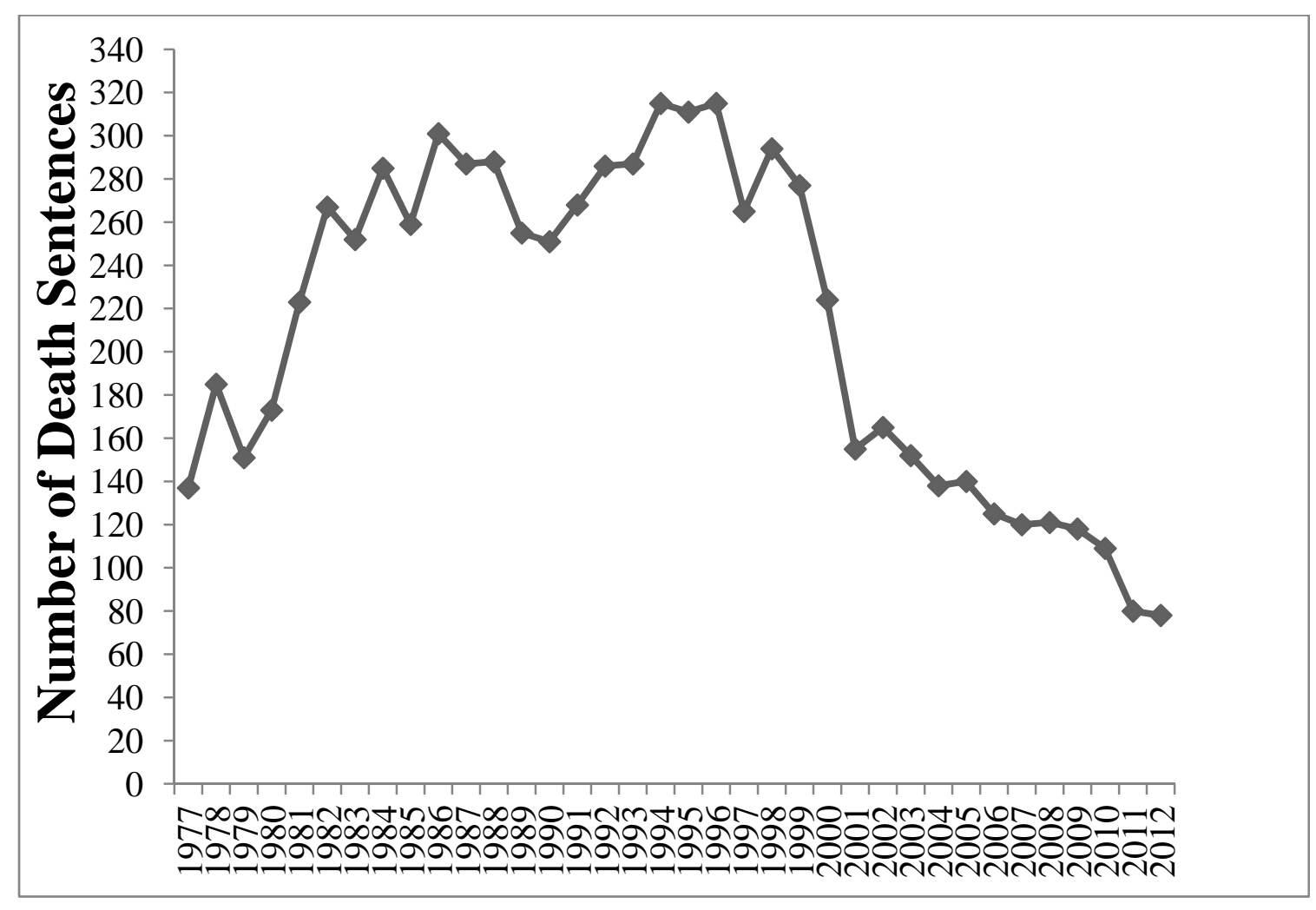

The Court's erroneous prediction in Gregg raises an important question: do social and numerical arbitrariness remain? The answer regarding social arbitrariness is clear-a multitude of studies suggest that race and class continue to influence capital punishment [16-22]. Although numerical arbitrariness has not been studied as extensively, the limited empirical record is troubling. Consider the following.

5 Breadth is further expanded if an aggravator can be applied to non-killers, a question examined by Kamin and Marceau [14].

6 It is true that state courts have attempted to narrow the scope of some broad aggravators, but such efforts have not been comprehensive. In addition, such efforts are often futile. Focusing on the heinous/atrocious/cruel aggravator and using Arizona as an example, Kirchmeier notes that attempts to clarify the aggravator rely on equally vague and encompassing language such as "gratuitous violence" and the "senselessness of the murders" ([10], p. 365). Kirchmeier ([10], p. 368) quotes the Chief Justice of the Arizona Supreme Court: “If there is some 'real science' to separating 'especially' heinous, depraved, or cruel killers from 'ordinary' heinous, depraved, or cruel killers, it escapes me. It has also escaped the court.” 
In Furman, the Supreme Court ruled that a death sentence rate of $15 \%$ to $20 \%$ was unconstitutional-the equivalent of drawing a name out of a hat (the death sentence rate is the percentage of death-eligible defendants who are actually sentenced to death). ${ }^{7}$ Steven Shatz [23] explains:

When the Court decided in Furman that the death penalty, as then administered by the states, created too great a risk of arbitrariness, it was the Justices' understanding that only $15 \%-20 \%$ of death-eligible murderers were sentenced to death. This was the figure cited by Chief Justice Burger, writing for the four dissenters, and he based his estimate on four sources. Justice Stewart, in turn, cited to the Chief Justice's statement as support for his conclusion that the imposition of death was 'unusual.' In Gregg v. Georgia, the plurality reiterated this understanding: 'It has been estimated that before Furman less than [20\%] of those convicted of murder were sentenced to death in those States that authorized capital punishment.' It was this fact - that fewer than one in five statutorily death-eligible defendants were being sentenced to death in the absolute discretion of the sentencer-that caused the Justices in Furman to find that the death penalty was 'exacted with great infrequency,' was 'so wantonly and so freakishly imposed' as to be like 'being struck by lightning,' and, consequently, was inescapably arbitrary (pp. 745-46).

Yet modern research suggests that the death sentence rate is $11 \%$ in California ([24], p. 1332), 4\% in Connecticut ([25], p. 4), and less than 1\% in Colorado ([26], pp. 1071-72).

The research record in Texas is also imbalanced. Despite several studies on social arbitrariness [27-36], we are not aware of a single study in Texas devoted to numerical arbitrariness. The purpose of the current research is to begin filling the gap by estimating the death sentence rate in Texas during the period from 2006 to 2010. Estimating the death sentence rate is important for each state that retains capital punishment; if the death sentence rate falls below the critical threshold established in Furman then the state's capital punishment system is unconstitutional as administered. After all, the constitutional principle established in Furman has never been repudiated ([24], pp. 1338-39). Instead, the principle has been affirmed in Zant v. Stephens (1983) [37], ${ }^{8}$ Pulley v. Harris (1984) [38], ${ }^{9}$ McCleskey v. Kemp (1987) [39], ${ }^{10}$ California v. Brown (1987) [40], ${ }^{11}$ Maynard v. Cartwright (1988) [41], ${ }^{12}$ Walton v. Arizona (1988) [42], ${ }^{13}$ and Tuilaepa v. California (1994) [43]. ${ }^{14}$

7 Justice Burger: "Although accurate figures are difficult to obtain, it is thought that from 15 to $20 \%$ of those convicted of murder are sentenced to death in States where it is authorized" ([1], footnote 11, p. 387). Justice Powell: "No fully reliable statistics are available on the nationwide ratio of death sentences to cases in which death was a statutorily permissible punishment. At oral argument, counsel for petitioner in No. 69-5003 estimated that the ratio is 12 or 13 to one. Others have found a higher correlation one out of every five or $20 \%$ of persons convicted of murder received the death penalty in California” ([1], footnote 19, p. 436).

8 Justice Stevens: "To avoid this constitutional flaw, an aggravating circumstance must genuinely narrow the class of persons eligible for the death penalty and must reasonably justify the imposition of a more severe sentence on the defendant compared to others found guilty of murder” ([37], p. 877).

9 Justice White: "Thus, the emphasis was on the constitutionally necessary narrowing function of statutory aggravating circumstances" ([38], p. 50).

10 Justice Powell: "In sum, our decisions since Furman have identified a constitutionally permissible range of discretion in imposing the death penalty. First, there is a required threshold below which the death penalty cannot be imposed. In this context, the State must establish rational criteria that narrow the decisionmaker's judgment as to whether the circumstances of a particular defendant's case meet the threshold” ([39], p. 305). 
Focusing on Texas is also important for two additional reasons. To begin, Texas leads the nation in executions accounting for 508 of the 1,359 executions in the United States from Gregg through 2013 [15]. Even more importantly for the research question at hand, Texas offers a conservative test that can provide broad insights. Reproduced in Table 1, the Texas capital murder statute is a partial exception to the rule of ever-expanding death eligibility - the statute includes a significant number of aggravators, but the statute does not include any of the broad aggravators outlined above that substantially widen the net (technically, Texas defines eligibility through the elements of capital murder rather than aggravators, but elements and aggravators are functionally equivalent-a topic we consider below) [44]. To situate Texas in the landscape of statutes, Table 2 examines the distribution of broad aggravators across the 32 current death penalty states: 3 states do not have any broad aggravators; 10 states have 1-2 broad aggravators; and 19 states have 3-5 broad aggravators [10]. Such a distribution demonstrates the nature of a conservative test: if the death sentence rate in Texas falls below the critical threshold despite the absence of broad aggravators then the death sentence rate presumably falls below the critical threshold in states with broad aggravators (broad aggravators enlarge the pool of death-eligible defendants; enlarging the pool depresses the death sentence rate unless the number of death sentences keeps pace, an improbable scenario in an era of plummeting death sentences).

Table 1. Texas Capital Murder Statute [44].

Sec. 19.03. CAPITAL MURDER. (a) A person commits an offense if the person commits murder as defined under Section 19.02(b)(1) and:

(1) the person murders a peace officer or fireman who is acting in the lawful discharge of an official duty and who the person knows is a peace officer or fireman;

(2) the person intentionally commits the murder in the course of committing or attempting to commit kidnapping, burglary, robbery, aggravated sexual assault, arson, obstruction or retaliation, or terroristic threat under Section 22.07(a)(1), (3), (4), (5), or (6);

(3) the person commits the murder for remuneration or the promise of remuneration or employs another to commit the murder for remuneration or the promise of remuneration;

(4) the person commits the murder while escaping or attempting to escape from a penal institution;

11 Chief Justice Rehnquist: “The Constitution instead requires that death penalty statutes be structured so as to prevent the penalty from being administered in an arbitrary and unpredictable fashion” ([40], p. 541).

12 Justice White: “Since Furman, our cases have insisted that the channeling and limiting of the sentencer's discretion in imposing the death penalty is a fundamental constitutional requirement for sufficiently minimizing the risk of wholly arbitrary and capricious action” ([41], p. 362).

13 Justice Scalia: "The case that began the development of this Eighth Amendment jurisprudence was Furman v. Georgia, which has come to stand for the principle that a sentencer's discretion to return a death sentence must be constrained by specific standards, so that the death penalty is not inflicted in a random and capricious fashion” ([42], p. 657).

14 Justice Kennedy: “As we have explained, the aggravating circumstance must meet two requirements. First, the circumstance may not apply to every defendant convicted of a murder; it must apply only to a subclass of defendants convicted of murder. Second, the aggravating circumstance may not be unconstitutionally vague” ([43], p. 972). 
Table 1. Cont.

(5) the person, while incarcerated in a penal institution, murders another:

(A) who is employed in the operation of the penal institution; or

(B) with the intent to establish, maintain, or participate in a combination or in the profits of a combination;

(6) the person:

(A) while incarcerated for an offense under this section or Section 19.02, murders another; or

(B) while serving a sentence of life imprisonment or a term of 99 years for an offense under Section 20.04,

22.021, or 29.03, murders another;

(7) the person murders more than one person:

(A) during the same criminal transaction; or

(B) during different criminal transactions but the murders are committed pursuant to the same scheme or cours of conduct;

(8) the person murders an individual under 10 years of age; or

(9) the person murders another person in retaliation for or on account of the service or status of the other person as a judge or justice of the supreme court, the court of criminal appeals, a court of appeals, a district court, a criminal district court, a constitutional county court, a statutory county court, a justice court, or a municipal court.

(b) An offense under this section is a capital felony.

(c) If the jury or, when authorized by law, the judge does not find beyond a reasonable doubt that the defendant is guilty of an offense under this section, he may be convicted of murder or of any other lesser included offense.

Added by Acts 1973, 63rd Leg., p. 1123, ch. 426, art. 2, Sec. 1, eff. Jan. 1, 1974. Amended by Acts 1983, 68th Leg., p. 5317, ch. 977, Sec. 6, eff. Sept. 1, 1983; Acts 1985, 69th Leg., ch. 44, Sec. 1, eff. Sept. 1, 1985; Acts 1991, 72nd Leg., ch. 652, Sec. 13, eff. Sept. 1, 1991; Acts 1993, 73rd Leg., ch. 715, Sec. 1, eff. Sept. 1, 1993; Acts 1993, 73rd Leg., ch. 887, Sec. 1, eff. Sept. 1, 1993; Acts 1993, 73rd Leg., ch. 900, Sec. 1.01, eff. Sept. 1, 1994; Acts 2003, 78th Leg., ch. 388, Sec. 1, eff. Sept. 1, 2003.

Amended by:

Acts 2005, 79th Leg., Ch. 428, Sec. 1, eff. September 1, 2005.

Acts 2011, 82nd Leg., R.S., Ch. 1209, Sec. 1, eff. September 1, 2011.

Table 2. Distribution of Broad Aggravators Across Death Penalty States [10].

\begin{tabular}{|c|c|c|c|c|c|c|c|}
\hline State & $\#$ & $\begin{array}{l}\text { Heinous, } \\
\text { Atrocious, } \\
\text { Cruel }^{1}\end{array}$ & $\begin{array}{l}\text { Grave Risk } \\
\text { Death to } \\
\text { Others }^{2}\end{array}$ & $\begin{array}{l}\text { Prior } \\
\text { Serious or } \\
\text { Violent } \\
\text { Felony } \\
\end{array}$ & $\begin{array}{l}\text { Under } \\
\text { Correctional } \\
\text { Supervision }^{4}\end{array}$ & $\begin{array}{l}\text { Lying in } \\
\text { Wait }^{5}\end{array}$ & Premeditated $^{6}$ \\
\hline Colorado & 5 & $\mathrm{Y}$ & $\mathrm{Y}$ & $\mathrm{Y}$ & $\mathrm{Y}$ & $\mathrm{Y}$ & \\
\hline Florida & 5 & $\mathrm{Y}$ & $\mathrm{Y}$ & $\mathrm{Y}$ & $\mathrm{Y}$ & & $\mathrm{Y}$ \\
\hline Alabama & 4 & $\mathrm{Y}$ & $\mathrm{Y}$ & $\mathrm{Y}$ & $\mathrm{Y}$ & & \\
\hline Kansas & 4 & $\mathrm{Y}$ & $\mathrm{Y}$ & $\mathrm{Y}$ & $\mathrm{Y}$ & & \\
\hline Mississippi & 4 & $\mathrm{Y}$ & $\mathrm{Y}$ & $\mathrm{Y}$ & $\mathrm{Y}$ & & \\
\hline Nevada & 4 & $\mathrm{Y}$ & $\mathrm{Y}$ & $\mathrm{Y}$ & $\mathrm{Y}$ & & \\
\hline $\begin{array}{l}\text { New } \\
\text { Hampshire }\end{array}$ & 4 & $\mathrm{Y}$ & $\mathrm{Y}$ & $\mathrm{Y}$ & & & $\mathrm{Y}$ \\
\hline Wyoming & 4 & $\mathrm{Y}$ & $\mathrm{Y}$ & $\mathrm{Y}$ & $\mathrm{Y}$ & & \\
\hline Arizona & 3 & $\mathrm{Y}$ & $\mathrm{Y}$ & $\mathrm{Y}$ & & & \\
\hline
\end{tabular}


Table 2. Cont.

\begin{tabular}{|c|c|c|c|c|c|c|c|}
\hline Arkansas & 3 & $\mathrm{Y}$ & $\mathrm{Y}$ & $\mathrm{Y}$ & & & \\
\hline Missouri & 3 & $\mathrm{Y}$ & $\mathrm{Y}$ & $\mathrm{Y}$ & & & \\
\hline Montana & 3 & $\mathrm{Y}$ & $\mathrm{Y}$ & & & $\mathrm{Y}$ & \\
\hline Nebraska & 3 & $\mathrm{Y}$ & $\mathrm{Y}$ & $\mathrm{Y}$ & & & \\
\hline $\begin{array}{l}\text { North } \\
\text { Carolina }\end{array}$ & 3 & $\mathrm{Y}$ & $\mathrm{Y}$ & $\mathrm{Y}$ & & & \\
\hline Oklahoma & 3 & $\mathrm{Y}$ & $\mathrm{Y}$ & & $\mathrm{Y}$ & & \\
\hline Pennsylvania & 3 & $\mathrm{Y}$ & $\mathrm{Y}$ & $\mathrm{Y}$ & & & \\
\hline $\begin{array}{l}\text { South } \\
\text { Dakota }\end{array}$ & 3 & $\mathrm{Y}$ & $\mathrm{Y}$ & $\mathrm{Y}$ & & & \\
\hline Tennessee & 3 & $\mathrm{Y}$ & $\mathrm{Y}$ & $\mathrm{Y}$ & & & \\
\hline Utah & 3 & $\mathrm{Y}$ & $\mathrm{Y}$ & $\mathrm{Y}$ & & & \\
\hline California & 2 & $\mathrm{Y}$ & & & & $\mathrm{Y}$ & \\
\hline Delaware & 2 & $\mathrm{Y}$ & & & & & $\mathrm{Y}$ \\
\hline Georgia & 2 & $\mathrm{Y}$ & $\mathrm{Y}$ & & & & \\
\hline Idaho & 2 & $\mathrm{Y}$ & $\mathrm{Y}$ & & & & \\
\hline Indiana & 2 & $\mathrm{Y}$ & & & & $\mathrm{Y}$ & \\
\hline Kentucky & 2 & & $\mathrm{Y}$ & $\mathrm{Y}$ & & & \\
\hline Louisiana & 2 & $\mathrm{Y}$ & & $\mathrm{Y}$ & & & \\
\hline Ohio & 1 & & $\mathrm{Y}$ & & & & \\
\hline $\begin{array}{l}\text { South } \\
\text { Carolina }\end{array}$ & 1 & & $\mathrm{Y}$ & & & & \\
\hline Virginia & 1 & $\mathrm{Y}$ & & & & & \\
\hline Oregon & 0 & & & & & & \\
\hline Texas & 0 & & & & & & \\
\hline Washington & 0 & & & & & & \\
\hline
\end{tabular}

Notes: ${ }^{1}$. See [10] note $348 ;{ }^{2}$. See [10] note $356 ;{ }^{3}$. See [10] note 374. In this category, Kirchmeier also includes: Montana, Georgia, Idaho, California, and South Carolina. We do not include such states because the statutes specify a prior murder and thus are more restrictive than a prior serious or violent felony; ${ }^{4}$. See [10] note 375. In this category, Kirchmeier also includes: Montana, Arizona, Georgia, Louisiana, Missouri, North Carolina, South Dakota, Tennessee, Utah, Delaware, Kentucky, Ohio, Washington, and Texas. We do not include such states because the statutes specify that the offender is in custody and thus are more restrictive than being under a sentence of imprisonment (which could mean probation or parole); ${ }^{5}$. See [10] note 359; ${ }^{6}$. See [10] note 358 .

To anticipate, our findings suggest that the death sentence rate in Texas falls between 3\% and 6\% depending on different assumptions that can be made about the data. Although it is not clear what death sentence rate would pass constitutional muster, it is clear from the Court's decision in Furman that a death sentence rate of $20 \%$ or less would not ([24], p. 1289). Given the enduring relevance of the Furman principle, our data suggest that the modern Texas death penalty is unconstitutional-a fatal lottery. If death is a bolt of lightning in Texas despite the absence of broad aggravators then death is presumably a bolt of lightning across the remaining states that sanction execution. 


\section{Narrowing the Pool of Death-Eligible Defendants in Texas}

The guided discretion statutes that were deemed constitutional in Gregg differed significantly from one another. The Georgia and Florida statutes followed the Model Penal Code's recommendation: narrow the pool of death-eligible defendants to the "worst of the worst" by defining murder broadly and then requiring the prosecution to prove the existence of a statutory aggravator — such as killing a police officer-during the penalty phase of the trial $[45,46]$. But Texas charted a different course to arrive at the same destination. Specifically, the Texas legislature narrowed the pool of death-eligible defendants to the "worst of the worst" through the definition of capital murder. In Texas, capital murder is restricted to murders that are committed intentionally or knowingly and include an additional element, such as killing a police officer $[45,46]$. The prosecution must prove the statutorily defined element during the guilt/innocence phase of the trial to secure a conviction for capital murder [45]. Having convicted the defendant of capital murder, Texas jurors must answer special sentencing issues during the punishment phase of the trial. To begin, jurors must decide "whether there is a probability that the defendant would commit criminal acts of violence that would constitute a continuing threat to society" [47]. If so, jurors must decide "whether, taking into consideration all of the evidence, including the circumstances of the offense, the defendant's character and background, and the personal moral culpability of the defendant, there is a sufficient mitigating circumstance or circumstances to warrant that a sentence of life imprisonment without parole rather than a death sentence be imposed" [47]. If the answers are "yes" and "no" then the judge sentences the defendant to death.

So who is eligible for the death penalty in Texas? The answer: A defendant who could be convicted of capital murder in the guilt/innocence phase. Dix and Schmolesky [46] explain:

The legislatively defined offense was more restrictive and accomplished a narrowing of death eligibility before the case arrived at the punishment phase. The Supreme Court approved of this guilt/innocence phase legislative narrowing as the equivalent of aggravating factors ([46], p. 1).

The special sentencing issues considered in the punishment phase-future dangerousness and mitigating circumstances-provide guidance regarding which defendants should be sentenced to death among those who are eligible. Dix and Schmolesky [46] continue:

While the Model Penal Code paradigm of aggravating and mitigating factors accomplished both the required narrowing and the jury guidance, Texas accomplished narrowing at the guilt/innocence phase and the special issues arguably provided guidance at the punishment phase. If the jury had been given unbridled discretion following the eligibility determination of the guilt/innocence stage, the Texas system would have failed to win the approval of the Court because there would be none of the guidance that Gregg required after the class of those determined to be eligible was narrowed ([46], p. 2).

Thus, eligibility is defined by the elements of capital murder and selection is guided by the special sentencing issues. $^{15}$

The differences across statutes are meaningful: Most states narrowed the pool by specifying aggravators that must be proved during the penalty phase of the trial, but Texas narrowed the pool by

15 Some have argued that death-eligibility in Texas is defined by the elements of capital murder and a finding of future dangerousness [48]. However, this is not the prevailing view [46]. 
specifying elements of capital murder that must be proved during the guilt/innocence phase of the trial [45]. Nonetheless, the Court concluded that the elements of capital murder in Texas are the functional equivalent of aggravators in most states [46]. Justice Stevens wrote in Jurek v. Texas (1976):

We conclude that Texas' capital sentencing procedures, like those of Georgia and Florida, do not violate the Eighth and Fourteenth Amendments. By narrowing its definition of capital murder, Texas has essentially said that there must be at least one statutory aggravating circumstance in a first-degree murder case before a death sentence may even be considered ([7], p. 276).

Given the functional equivalence of elements and aggravators, we use the more common and simpler term "aggravator" throughout the paper to avoid unnecessary confusion.

\section{Estimating the Death Sentence Rate in Texas}

We estimate the death sentence rate in Texas from 2006 to 2010. In 2005, the Texas legislature passed Senate Bill 60 giving capital jurors two sentencing options: death or life without parole (LWOP). SB 60 represented a significant legal turning point-prior to the passage of the bill capital jurors in Texas chose between death and life with the possibility of parole after 40 years. Thus, SB 60 provides a logical place to begin our investigation of numerical arbitrariness in the modern Texas death penalty system. Because the bill became effective in September 2005, we chose 2006 as the starting point for data collection [49]. ${ }^{16}$ We chose 2010 as the ending point for data collection under the assumption that virtually all the defendants who were going to be sentenced to death for murders committed between 2006 and 2010 would have arrived on death row by December 2013 (the month we concluded data analysis).

The death sentence rate has two components: the numerator is the number of defendants who were sentenced to death for capital murders committed in Texas during the time period in question; the denominator is the number of defendants who were eligible to be sentenced to death for capital murders committed in Texas during the time period in question (the proportion is multiplied by 100 to produce a percentage).

Data for the numerator were drawn from the Texas Department of Criminal Justice website [50]. The website indicates that 38 defendants were sentenced to death for murders committed between 2006 and 2010. The defendants in question are listed in Table 3 (the table also includes information regarding the date of the murder, the date the defendant arrived on death row, the county of conviction, the statutory aggravator, and the race/gender of the defendant and victim).

16 We are not suggesting that SB 60 is responsible for the low death sentence rate in Texas. Indeed, the death sentence rate might have been lower, higher, or the same in prior historical periods. The death sentence rate is a product of several factors and we do not have the data to comment on changes over time and the potential role of SB 60 in such changes. Rather than implying a causal relationship, we simply treat SB 60 as a significant legal change and a natural place to begin our investigation of numerical arbitrariness in the modern Texas system. 
Table 3. Defendants Sentenced to Death in Texas for Murders that Occurred from 2006 to 2010 [50].

\begin{tabular}{|c|c|c|c|c|c|c|}
\hline Name & $\begin{array}{l}\text { Date of } \\
\text { Murder }\end{array}$ & $\begin{array}{l}\text { Date } \\
\text { Received } \\
\text { Death Row } \\
\end{array}$ & County & Aggravator & $\begin{array}{l}\text { Race/Gender } \\
\text { Defendant }\end{array}$ & $\begin{array}{l}\text { Race/Gender } \\
\text { Victim }\end{array}$ \\
\hline Andrus, Terence & $10 / 15 / 2008$ & $11 / 19 / 2012$ & Fort Bend & 5 & $\mathrm{BM}$ & AF HM \\
\hline Griffin, Stanley & 09/19/2010 & $07 / 02 / 2012$ & Brazos & 1 & $\mathrm{BM}$ & WF \\
\hline Harris, Roderick & 03/01/2009 & 06/13/2012 & Dallas & 1,5 & $\mathrm{BM}$ & HM HM \\
\hline Cargill, Kimberly & 06/01/2010 & 06/07/2012 & Smith & 7 & WF & $\mathrm{BF}$ \\
\hline Soliz, Mark & 06/29/2010 & $03 / 28 / 2012$ & Johnson & 1 & HM & WF \\
\hline Rockwell, Kwame & $02 / 23 / 2010$ & 01/30/2012 & Tarrant & $1,4,5$ & BM & HM WM \\
\hline Cole, Jaime & $02 / 04 / 2010$ & $11 / 23 / 2011$ & Harris & 5 & $\mathrm{HM}$ & WF WF \\
\hline Batiste, Tedderick & $04 / 19 / 2009$ & $07 / 27 / 2011$ & Harris & 1 & BM & $\mathrm{BM}$ \\
\hline Hummel, John & $12 / 17 / 2009$ & 06/29/2011 & Tarrant & $4,5,6$ & WM & WM WF WF \\
\hline Jean, Joseph & $04 / 11 / 2010$ & 06/23/2011 & Harris & 4,5 & $\mathrm{BM}$ & $\mathrm{BF} \mathrm{BF}$ \\
\hline Turner, Albert & $12 / 27 / 2009$ & $06 / 10 / 2011$ & Fort Bend & 5 & $\mathrm{BM}$ & WF WF \\
\hline Escobar, Areli & 05/31/2009 & $05 / 26 / 2011$ & Travis & 2 & $\mathrm{HM}$ & $\mathrm{HF}$ \\
\hline Mullis, Travis & $01 / 29 / 2008$ & $05 / 23 / 2011$ & Galveston & 2,6 & WM & WM \\
\hline Robinson, Cortne & 09/20/2009 & $03 / 23 / 2011$ & Harrison & 1 & $\mathrm{BM}$ & WM \\
\hline Green, Gary & 09/22/2009 & $11 / 22 / 2010$ & Dallas & 5 & BM & $\mathrm{BF}$ BF \\
\hline Harper, Garland & $10 / 24 / 2008$ & $10 / 22 / 2010$ & Harris & 5 & $\mathrm{BM}$ & BF BF BF \\
\hline Milam, Blaine & $12 / 02 / 2008$ & 06/11/2010 & Rusk & 2,6 & WM & WF \\
\hline Thuesen, John & 03/06/2009 & $05 / 28 / 2010$ & Brazos & 5 & WM & WF WM \\
\hline Landor III, Mabry & $12 / 07 / 2008$ & $04 / 16 / 2010$ & Harris & 3 & $\mathrm{BM}$ & WM \\
\hline Lopez, Daniel & 03/11/2009 & 03/16/2010 & Nueces & 3 & HM & WM \\
\hline Hernandez, Fabian & $11 / 03 / 2006$ & $02 / 09 / 2010$ & El Paso & 5 & HM & HF HM \\
\hline Martin, Jerry & $09 / 24 / 2007$ & $12 / 17 / 2009$ & Leon & 3 & WM & WF \\
\hline Miller, Demontrell & $06 / 01 / 2008$ & $11 / 19 / 2009$ & Smith & 6 & $\mathrm{BM}$ & $\mathrm{BM}$ \\
\hline Devoe, Paul & 08/02/2007 & 10/16/2009 & Travis & 5 & WM & $\begin{array}{l}\text { WM WF WF } \\
\text { WF }\end{array}$ \\
\hline Broadnax, James & 06/19/2008 & $09 / 02 / 2009$ & Dallas & 5 & BM & WM WM \\
\hline Leza, Armando & $04 / 04 / 2007$ & 06/09/2009 & Bexar & 1,4 & HM & WF \\
\hline Olsen, Christian & 06/03/2007 & 03/04/2009 & Brazos & 1 & WM & WF \\
\hline Davila, Erick & 04/06/2008 & $02 / 27 / 2009$ & Tarrant & 5,6 & $\mathrm{BM}$ & $\mathrm{BF} \mathrm{BF}$ \\
\hline Sparks, Robert & 09/15/2007 & $01 / 08 / 2009$ & Dallas & 2,5 & $\mathrm{BM}$ & BF BM BM \\
\hline Freeman, James & $03 / 17 / 2007$ & $10 / 11 / 2008$ & Wharton & 3 & WM & WM \\
\hline Storey, Paul & $10 / 16 / 2006$ & $09 / 16 / 2008$ & Tarrant & 1 & $\mathrm{BM}$ & WM \\
\hline Lucio, Melissa & $02 / 17 / 2007$ & $08 / 12 / 2008$ & Cameron & 6 & $\mathrm{HF}$ & $\mathrm{HF}$ \\
\hline Ruiz, Wesley & $03 / 23 / 2007$ & $07 / 16 / 2008$ & Dallas & 3 & $\mathrm{HM}$ & WM \\
\hline Mays, Randall & $05 / 17 / 2007$ & $05 / 16 / 2008$ & Henderson & 3,5 & WM & WM BM \\
\hline Williams, Antonio & $08 / 05 / 2006$ & $12 / 28 / 2007$ & Harris & 5 & $\mathrm{BM}$ & $\mathrm{BM} \mathrm{BF}$ \\
\hline $\begin{array}{l}\text { Chanthakoummane, } \\
\text { Kosoul }\end{array}$ & 07/08/2006 & $10 / 18 / 2007$ & Collin & 1 & $\mathrm{AM}$ & WF \\
\hline Johnson, Dexter & 06/18/2006 & $07 / 02 / 2007$ & Harris & $1,2,5$ & BM & AM AF \\
\hline $\begin{array}{l}\text { Armstrong, } \\
\text { Douglas }\end{array}$ & $04 / 21 / 2006$ & 01/30/2007 & Hidalgo & 1 & $\mathrm{BM}$ & HM \\
\hline
\end{tabular}

Notes: Codes for aggravators: $1=$ robbery, $2=$ rape, $3=$ police victim, $4=$ arson, $5=$ multiple victims, $6=$ child victim, 7 = obstruction. 
Data for the denominator were drawn from Supplemental Homicide Reports (SHR) [51]. ${ }^{17}$ Collected as part of the FBI's annual Uniform Crime Report, SHR data provide information on all homicide incidents reported to the police across the United States. We began by narrowing the data to homicide incidents in Texas from 2006 to 2010. Next, we transformed the data from 6,820 homicide incidents to 8,173 "potential homicide defendants"-individuals who could have been arrested for homicide (the data must be disaggregated because one incident can include multiple people who are death-eligible). ${ }^{18}$ Throughout the remainder of the paper, we refer to "potential homicide defendants" as "defendants" to avoid such a cumbersome term (even though some of the individuals in question were not arrested).

Of the 8,173 defendants, how many were eligible for death? The initial criterion is the presence of an aggravator. The SHR data indicate whether the murder included any of the following aggravators in the Texas statute: child victim; multiple victims; murder during the commission of a robbery, burglary, or sexual assault; and murder by arson. Although the SHR data do not specify whether the victim was a police officer or corrections officer, we used the “Officer Down Memorial Page” website to identify such cases [53]. Unfortunately, the SHR data do not include information about the remaining aggravators in the Texas statute. But murders involving the remaining aggravators—such as killing a firefighter, killing a judge, killing a witness to prevent the person from testifying, killing during a prison escape, hiring a hit man, and kidnapping the victim-are less common. Also, such defendants would already be counted as death-eligible if the murder involved an aggravator that is included in the SHR data. For example, a defendant who kidnapped the victim would often be counted as death-eligible for raping or robbing the victim (or killing a child, or killing multiple victims, and so forth). Nonetheless, the fact that some Texas aggravators are not included in the SHR data means that the denominator in the death sentence rate is an undercount. Yet such an "error" actually produces a conservative estimate of the death sentence rate: if more death-eligible defendants were added to the denominator then the death sentence rate would be even lower.

To be eligible for death a defendant must also be arrested, convicted, and 18 or older at the time of the crime based on the Court's decision in Roper v. Simmons (2005) [54]. To determine if a suspect was arrested we follow the convention in the field; if the SHR data do not include the race and sex of the suspect then we assume that the suspect has not been arrested [55]. Because the Bureau of Justice Statistics (BJS) indicates that $81 \%$ of the defendants who are arrested for murder are convicted, we assume that the same percentage holds true in our data [56]. Finally, the SHR data report the age of the defendant, so we eliminated juveniles who were under 18 at the time of the crime (below, we also consider whether codefendants were death-eligible).

\section{The Death Sentence Rate in Texas: A Conservative Approach}

Recall the Court's logic in Gregg: guided discretion statutes would solve the problem of arbitrariness because state legislatures would narrow the pool of death-eligible defendants to "the worst of the worst" and most would be sentenced to death. If most death-eligible defendants were

17 Fagan and colleagues [52] use a similar approach to determine death-eligibility in a study of deterrence.

18 Homicide incidents coded in the SHR data as manslaughter by negligence were eliminated. 
sentenced to death then social and numerical arbitrariness would disappear. Do the empirical data support such a prediction in Texas from 2006 to 2010?

Table 4 provides different estimates of the death sentence rate in Texas based on different assumptions about the data. Of the 8,173 defendants, Panel A reports that 1,820 committed a murder with an aggravator. Of those with an aggravator, 1,524 were arrested. After eliminating juveniles, 1,384 adult defendants were arrested for a murder that included an aggravator (if the age of the defendant is missing in the SHR data then we assume the person is an adult; below, we change that assumption). Assuming a conviction rate of $81 \%$ reveals that 1,121 defendants were eligible for death $\left(81^{*} 1,384\right)$. Yet only 38 defendants were sentence to death-a death sentence rate of 3\% $(38 / 1,121)$. However, the SHR data are missing the age of the defendant in 203 cases. Although most are probably adults, we cannot be sure. Consequently, the most conservative approach is to assume that the 203 defendants in question are juveniles and thus ineligible for death (such an approach inflates our estimate of the death sentence rate by reducing the pool of death-eligible defendants). Panel B reports our revised estimate. Specifically, the 1,384 adult defendants referenced above are reduced to 1,181 adult defendants $(1,384-203)$ with the assumption that 957 are convicted $(81 * 1,181)$. But even after revising the denominator downward the death sentence rate only climbs to $4 \%$ (38/957). Turning to Panel C, we offer an even more conservative estimate of the death sentence rate. Here, we consider whether codefendants should be considered death-eligible. In Enmund v. Florida (1982) and Tison v. Arizona (1987) [57,58], the Supreme Court distinguished between minor participation and major participation in a capital murder, concluding that major participation is required to be eligible for death. Although most of the codefendants were probably major participants, we cannot be sure. So we assume that the 279 codefendants in question were minor participants and thus ineligible, again erring on the side of caution. Still, reducing the denominator from 1181 defendants to 902 defendants and assuming that 731 are convicted $(81 * 902)$ only increases the death sentence rate to 5\% $(38 / 731)$. Obviously, it is not reasonable to assume that all the defendants with missing data on age are juveniles or to assume that all the codefendants were minor participants. We do so to emphasize a key point: the death sentence rate in Texas from 2006 to 2010 falls substantially below the critical Furman threshold regardless of how the pool of death-eligible defendants is defined. Given that the substantive findings are robust across different specifications, we simplify our subsequent analyses by using the most conservative approach (based on the assumptions in Table 4, Panel C).

Table 4. Death Sentence Rate in Texas, 2006-2010.

\section{Panel A. Assume that Defendants Whose Age is Unknown are Adults}

\begin{tabular}{|l|c|}
\hline Defendants & 8,173 \\
\hline Defendants with Statutory Aggravator & 1,820 \\
\hline Defendants with Statutory Aggravator and Arrest & 1,524 \\
\hline Defendants with Statutory Aggravator, Arrest, and Adult & 1,384 \\
\hline Defendants Convicted (assuming 81\% rate of conviction) & 1,121 \\
\hline Defendants Sentenced to Death Death Sentence Rate: $\mathbf{3 8 / 1 , 1 2 1}=\mathbf{3 . 4 \%}$ & 38 \\
\hline \multicolumn{2}{|}{$\quad$ D }
\end{tabular}

Death Sentence Rate: $38 / 1,121=3.4 \%$ 
Table 4. Cont.

\begin{tabular}{|l|c|}
\hline Panel B. Assume that Defendants Whose Age is Unknown are Juveniles \\
\hline Defendants & 8,173 \\
\hline Defendants with Statutory Aggravator & 1,820 \\
\hline Defendants with Statutory Aggravator and Arrest & 1,524 \\
\hline Defendants with Statutory Aggravator, Arrest, and Adult & 1,384 \\
\hline Eliminate 203 Defendants Whose Age is Unknown and Might be Juveniles & 1,181 \\
\hline Defendants Convicted (assuming 81\% rate of conviction) & 957 \\
\hline Defendants Sentenced to Death Death Sentence Rate: 38/957 = 4.0\% & 38 \\
\hline \multicolumn{2}{|c|}{ Panel C. Exclude Codefendants and Assume that Defendants Whose Age is Unknown are Juveniles } \\
\hline Defendants & 8,173 \\
\hline Defendants with Statutory Aggravator & 1,820 \\
\hline Defendants with Statutory Aggravator and Arrest & 1,524 \\
\hline Defendants with Statutory Aggravator, Arrest, and Adult & 1,384 \\
\hline Eliminate 482 Because Codefendant and/or Age is Unknown and Might be Juveniles & 902 \\
\hline Defendants Convicted (assuming 81\% rate of conviction) & 731 \\
\hline Defendants Sentenced to Death Death Sentence Rate: 38/731 = 5.2\% & 38 \\
\hline \multicolumn{2}{|c|}{} \\
\hline
\end{tabular}

Beyond our statewide findings, we also estimate the death sentence rate in the handful of counties that send the largest number of defendants to death row. Although Texas has 254 counties, just four-Harris (Houston), Dallas (Dallas), Tarrant (Fort Worth and Arlington), and Bexar (San Antonio) —account for 532 of the 1,063 death sentences imposed in the state since Gregg [50]. Interestingly, Table 5 reveals that the death sentence rate is about the same in the most active death jurisdictions as the rest of the state, ranging from $2 \%$ to $10 \%$. In fact, only 17 of the combined 435 death-eligible defendants were sentenced to death-an overall death sentence rate of $4 \%$ in the selected counties.

Table 5. Death Sentence Rate in Key Counties.

\begin{tabular}{|l|l|c|c|c|c|}
\hline County & Major Cities & $\begin{array}{c}\text { Number Eligible After } \\
\text { Eliminating Codefendants } \\
\text { and/or Age Unknown }\end{array}$ & $\begin{array}{c}\text { Number } \\
\text { Convicted } \\
\mathbf{8 1 \%} \text { rate })\end{array}$ & $\begin{array}{c}\text { Number of } \\
\text { Death Sentences }\end{array}$ & $\begin{array}{c}\text { Death } \\
\text { Sentence } \\
\text { Rate }\end{array}$ \\
\hline Bexar & San Antonio & 77 & 62 & 1 & $2 \%$ \\
\hline Harris & Houston & 314 & 254 & 7 & $3 \%$ \\
\hline Dallas & Dallas & 96 & 78 & 5 & $6 \%$ \\
\hline Tarrant & $\begin{array}{l}\text { Fort Worth and } \\
\text { Arlington }\end{array}$ & 50 & 41 & 4 & $10 \%$ \\
\hline
\end{tabular}

We also examine whether some aggravators are more constitutionally infirm than others. Table 6 reveals that the death sentence rate falls below the critical threshold for the murder of a child (2\%), murder in the commission of a robbery-burglary (4\%), and the murder of multiple victims (10\%). But the death sentence rate is much higher for murder by arson (40\%), the murder of a police officer (40\%), and murder in the commission of a sexual assault (42\%). Such stark patterns are driven by an 
inverse relationship between the number of death-eligible defendants and the death sentence rate: common capital murders produce a lower death sentence rate, while rare capital murders produce a higher death sentence rate (for more on the role of prevalence in sentencing see [59]).

Table 6. Death Sentence Rate by Aggravator.

\begin{tabular}{|l|c|c|c|c|}
\hline \multicolumn{1}{|c|}{ Aggravator } & $\begin{array}{c}\text { Number Eligible After Eliminating } \\
\text { Codefendants and/or Age Unknown }\end{array}$ & $\begin{array}{c}\text { Number } \\
\text { Convicted } \\
(\mathbf{8 1 \%} \text { rate) }\end{array}$ & $\begin{array}{c}\text { Number of } \\
\text { Death } \\
\text { Sentences }\end{array}$ & $\begin{array}{c}\text { Death } \\
\text { Sentence Rate }\end{array}$ \\
\hline Child Victim & 302 & 245 & 6 & $2 \%$ \\
\hline Robbery-Burglary & 386 & 313 & 12 & $4 \%$ \\
\hline Multiple Victims & 213 & 173 & 18 & $10 \%$ \\
\hline Arson & 12 & 10 & 4 & $40 \%$ \\
\hline Police Victim & 18 & 15 & 6 & $40 \%$ \\
\hline Sexual Assault & 15 & 12 & 5 & $42 \%$ \\
\hline
\end{tabular}

Turning from numerical arbitrariness to social arbitrariness, we consider the influence of the victim's characteristics on death sentencing. Decades of research indicate that the death penalty is more likely to be imposed on behalf of white victims and, particularly, white female victims [16-19,35,60,61]. The current research is no exception. Table 7 reveals that $28 \%$ of the death-eligible defendants killed a white victim, yet 58\% (22/38) of the defendants who were sentenced to death killed a white victim. Considering the intersection of the victim's race and gender produces disparities that are even more striking: $11 \%$ of the death-eligible defendants killed a white female victim, yet $32 \%(12 / 38)$ of the defendants who were sentenced to death killed a white female victim. Thus, the rate of death sentencing on behalf of white victims is about double what one would expect if the system were blind to race (58\% versus $28 \%$ ), and the rate of death sentencing on behalf of white female victims is about triple what one would expect if the system were blind to race and gender (32\% versus $11 \%){ }^{19}$

Table 7. The Influence of Victim Race-Gender on Death Sentencing.

\begin{tabular}{|l|c|c|}
\hline \multicolumn{1}{|c|}{ Victim Race-Gender } & $\begin{array}{c}\text { Eligible After Eliminating Codefendants and/or Age } \\
\text { Unknown }\end{array}$ & $\begin{array}{c}\text { Death } \\
\text { Sentence }\end{array}$ \\
\hline Defendant Killed White Victim & $28 \%$ & $58 \%(22 / 38)$ \\
\hline $\begin{array}{l}\text { Defendant Killed White Female } \\
\text { Victim }\end{array}$ & $11 \%$ & $32 \%(12 / 38)$ \\
\hline
\end{tabular}

19 Moving beyond numerical and social arbitrariness, geographical arbitrariness is also apparent. Of the 254 counties in Texas, just 120 have sent a defendant to death row since the decision in Gregg. Moreover, just 88 of the 254 counties are responsible for all executions since Gregg [50]. 


\section{Conclusions}

For almost 40 years, the Court has attempted to regulate capital punishment. In Gregg, the Justices assumed that guided discretion statutes would solve the problem of arbitrariness identified in Furman. If state legislatures narrowed the pool of death-eligible defendants to the "worst of the worst" then most would be sentenced to death, eliminating arbitrariness. Yet numerous studies conclude that social arbitrariness remains [16-22,27-36,60,61] and several studies have documented continuing numerical arbitrariness [24-26]. Summarizing the failure of regulation, Steiker and Steiker describe modern capital punishment as the "worst of all possible worlds" ([12], p. 438). The authors note:

The Supreme Court's death penalty law, by creating an impression of enormous regulatory effort while achieving negligible regulatory effects, effectively obscures the true nature of our capital sentencing system, in which the pre-Furman world of unreviewable sentencer discretion lives on, with much the same consequences in terms of arbitrary and discriminatory sentencing patterns ([12], p. 436).

The purpose of the current research is to add another piece of the puzzle regarding numerical arbitrariness: Does the death sentence rate in Texas for the period from 2006 to 2010 fall below the critical threshold established in Furman? Our estimates suggest that the statewide death sentence rate in Texas ranges from $3 \%$ to $5 \%$ depending on assumptions made about the data (the general pattern holds true in the small number of counties that send the most defendants to death row). The paltry death sentence rate is driven by aggravators_-killing a child, killing during the commission of a robbery-burglary, and killing multiple victims - that substantially enlarge the pool of death-eligible defendants, but produce few death sentences. Though not the focus of our research, the data also suggest that social arbitrariness remains-death was more apt to be imposed on behalf of white victims and, especially, white female victims. Thus, death sentencing in Texas appears to be patterned yet random - a biased fatal lottery. If true, perhaps the correct meteorological metaphor is a tornado rather than a bolt of lightning; year after year, tornadoes cut a random path of destruction across the same geographical areas.

One might react to the current research by calling for more death sentences. Such a response is problematic for legal and practical reasons. From a legal perspective, the purpose of guided discretion statutes was to eliminate arbitrariness by narrowing the pool of death-eligible defendants—not by drastically increasing the number of death sentences. From a practical perspective, solving the constitutional conundrum through sentencing is not realistic. If, hypothetically, a $50 \%$ death sentence rate would pass constitutional muster then Texas would need to sentence 10 to 15 times more defendants to death during the time period in question. Beyond being implausible, such a strategy would increase the risk of executing innocent defendants while doing nothing to address racial disparities. The only solutions appear to be abolition or genuine legislative winnowing, perhaps restricting death-eligibility to a small number of aggravators such as killing a police officer and killing during the commission of a sexual assault (the death sentence rate for those aggravators is about $40 \%$ and would presumably increase if the statute were narrowed and prosecutorial resources were concentrated on a smaller number of crimes).

To be sure, the current research is imperfect. Could our estimates of the death sentence rate be wrong? Two errors are possible: (1) The number of defendants sentenced to death for capital murders 
that occurred in Texas from 2006 to 2010 could climb if investigations are continuing or trials are ongoing. But the number of defendants added to the numerator would presumably be small. Consider the following: of the 274 current death row inmates in Texas, 240 arrived within 3 years of the crime [50]. Thus, if we assume that the 38 defendants who have already been sentenced to death represent $88 \%$ (240/274) of the eventual total then the numerator in the death sentence rate could grow to 43 defendants (probably an overestimate given that most of the defendants in the data have had a longer period of time for the case to be disposed). (2) Our estimate of the denominator might also be slightly off the mark. Given the fact that the SHR data do not include information on all aggravators, we are missing some death-eligible defendants. Conversely, some defendants who appear to be death-eligible might be mentally retarded, and thus ineligible under Atkins v. Virgina (2002) [62]. The former number is probably greater than the latter number. If so, the denominator is still an undercount-meaning the true death sentence rate is even lower than our estimates suggest. Nonetheless, we follow our established practice of providing the most conservative estimate possible. Specifically, if we assume that the numerator could expand to 43 defendants, and we assume that the denominator remains the same at 731 defendants (based on the assumptions in Table 4, Panel C), then the maximum death sentence rate is $6 \%(43 / 731)$. Although pinpoint precision would be ideal, we submit that the death sentence rate is similar to horseshoes and hand grenades: if the most conservative possible estimate of the death sentence rate falls far below the critical threshold established in Furman then it is reasonable to conclude that the modern system of capital punishment in Texas is unconstitutional as currently administered. Put differently, the imperfections in the data do not threaten our substantive conclusion.

Not only do we provide a conservative estimate of the death sentence rate in Texas, we also provide a conservative test of whether the modern American death penalty is a fatal lottery. Remember that the death sentence rate in Texas falls below the critical Furman threshold despite the absence of broad aggravators found in most state statutes. Can we therefore conclude that the death penalty is imposed arbitrarily in such states? After all, the states in question have enlarged the pool of death-eligible defendants even more than Texas during an era of plummeting death sentences. The technical answer is no-empirical research is required in each jurisdiction to be certain. But our findings in Texas strongly suggest that the modern American death penalty is a fatal lottery. Or, perhaps more fittingly, the modern American death penalty is a tornado that kills predictably yet randomly.

It is important to note that the current research is just a beginning, as pivotal questions remain unanswered. Perhaps most centrally: has the death sentence rate in Texas changed over time from Gregg to the present? Does the low death sentence rate observed from 2006 to 2010 represent a continuation or a significant downward departure? A steady state is possible. For example, the number of death sentences imposed in the 1990's was much higher than the 2000's, but so too was the overall homicide rate. Nonetheless, death sentences have fallen even more precipitously than the overall homicide rate, suggesting that the problem of numerical arbitrariness might be getting worse. ${ }^{20}$

20 The number of death sentences in the United States dropped from a peak of 315 in 1996 to 78 in 2012 [15]. During the same period, the number of homicides dropped from 19,645 to 14,827 (or from a homicide rate of 7.4 per 100,000 to 4.7 per 100,000) [63]. Put differently, there were 4 times more death sentences in 1996 than 2012, compared to 1.3 times more homicides (or the homicide rate was 1.6 times higher). 
Answering the question would require the disaggregation of death-eligible murders from all homicides in Texas from Gregg to the present, an important task that falls beyond the current research.

\section{Acknowledgements}

For providing comments on the paper, we thank Paul Colomy, Mark Cooney, Justin Marceau, Lisa Pasko, and the anonymous reviewers.

\section{Author Contributions}

Alena Simon graduated with Departmental Distinction based on her Senior Honors Thesis entitled: “The Modern Texas Death Penalty: A Fatal Lottery.” Alena wrote her thesis under the direction of her advisor, Scott Phillips, an Associate Professor in the Department of Sociology and Criminology at the University of Denver. Scott then wrote the version of the paper published here.

\section{Conflicts of Interest}

The authors declare no conflict of interest.

\section{References and Notes}

1. Furman v. Georgia, 408 U.S. 238, decided 29 June 1972.

2. Marks v. United States, 430 U.S. 188, decided 1 March 1977.

3. Woodson v. North Carolina, 428 U.S. 280, decided 2 July 1976.

4. Roberts v. Louisiana, 431 U.S. 633, decided 6 June 1977.

5. $\quad$ Gregg v. Georgia, 428 U.S. 153, decided 2 July 1976.

6. $\quad$ Proffitt v. Florida, 428 U.S. 242, decided 2 July 1976.

7. Jurek v. Texas, 428 U.S. 262, decided 2 July 1976.

8. Raymond Paternoster, Robert Brame, and Sarah Bacon. The Death Penalty: America's Experience with Capital Punishment. New York: Oxford University Press, 2008.

9. Chelsea Creo Sharon. “The 'Most Deserving' of Death: The Narrowing Requirement and the Proliferation of Aggravating Factors in Capital Sentencing Statutes.” Harvard Civil Rights-Civil Liberties Law Review 46 (2011): 223-51.

10. Jeffrey L. Kirchmeier. “Aggravating and Mitigating Factors: The Paradox of Today's Arbitrary and Mandatory Capital Punishment Scheme.” William \& Mary Bill of Rights Journal 6 (1998): 345-459.

11. Jeffrey L. Kirchmeier. "Casting a Wider Net: Another Decade of Legislative Expansion of the Death Penalty in the United States.” Pepperdine Law Review 34 (2006): 1-40.

12. Carol S. Steiker, and Jordan M. Steiker. "Sober Second Thoughts: Reflections on Two Decades of Constitutional Regulation of Capital Punishment.” Harvard Law Review 109 (1995): 355-438.

13. Jonathan Simon, and Christina Spaulding. "Tokens of Our Esteem: Aggravating Factors in the Era of Deregulated Death Penalties.” In The Killing State: Capital Punishment in Law, Politics, and Culture. Edited by Austin Sarat. New York: Oxford University Press, 1999, pp. 81-113.

14. Sam Kamin, and Justin Marceau. "Vicarious Aggravators.” Florida Law Review 65 (2013): 769-812. 
15. Death Penalty Information Center. Available online: http://www.deathpenaltyinfo.org/ (accessed on 11 December 2013).

16. U.S.Government Accountability Office. "Death Penalty Sentencing: Resource Indicates Pattern of Racial Disparities.” Washington, DC: U.S. Government Accountability Office, 1990.

17. David C. Baldus, George Woodworth, and Charles A. Pulaski, Jr. Equal Justice and the Death Penalty: A Legal and Empirical Analysis. Boston: Northeastern University Press, 1990.

18. David C. Baldus, and George Woodworth. "Race Discrimination and the Death Penalty: An Empirical and Legal Overview.” In America's Experiment with Capital Punishment. Edited by James R. Acker, Robert M. Bohm, and Charles S. Lanier. Durham, North Carolina: Carolina Academic Press, 2003, pp. 501-51.

19. David C. Baldus, and George Woodworth. "Race Discrimination in the Administration of the Death Penalty: An Overview of the Empirical Evidence with Special Emphasis on the Post-1990 Research.” Criminal Law Bulletin 39 (2003): 194-226.

20. Baldus, David C., George Woodworth, David Zuckerman, Neil Alan Weiner, and Barbara Broffitt. "Racial Discrimination and the Death Penalty in the Post-Furman Era: An Empirical and Legal Overview, with Recent Findings from Philadelphia.” Cornell Law Review 83 (1998): 1638-770.

21. Baldus, David C., George Woodworth, Catherine M. Grosso, and Aaron M. Christ. "Arbitrariness and Discrimination in the Administration of the Death Penalty: A Legal and Empirical Analysis of the Nebraska Experience (1973-1999).” Nebraska Law Review 81 (2002): 486-756.

22. Radelet, Michael L. "Executions of Whites for Crimes against Blacks: Exceptions to the Rule?" The Sociological Quarterly 30, no. 4 (1989): 529-44.

23. Steven F. Shatz. "The Eighth Amendment, the Death Penalty, and Ordinary Robbery-Burglary Murderers: A California Case Study.” Florida Law Review 59 (2007): 719-70.

24. Steven F. Shatz, and Nina Rivkind. "The California Death Penalty Scheme: Requiem for Furman?” New York University Law Review 72 (1997): 1283-342.

25. John J. Donohue. "Capital Punishment in Connecticut, 1973-2007: A Comprehensive Evaluation from 4686 Murders to One Execution.” SelectedWorks of John Donohue, 2013. Available online: http://works.bepress.com/john_donohue/87 (accessed on 11 December 2013).

26. Justin Marceau, Sam Kamin, and Wanda Foglia. "Death Eligibility in Colorado: Many are Called, Few are Chosen.” University of Colorado Law Review 84 (2013): 1069-115.

27. William J. Bowers, and Glenn L. Pierce. "Arbitrariness and Discrimination under Post-Furman Capital Statutes.” Crime and Delinquency 26 (1980): 563-635.

28. Sheldon Ekland-Olson. "Structured Discretion, Racial Bias, and the Death Penalty: The First Decade after Furman in Texas.” Social Science Quarterly 69 (1988): 853-73.

29. Jonathan R. Sorensen, and James W. Marquart. "Prosecutorial and Jury Decision-Making in PostFurman Texas Capital Cases.” NYU Review of Law and Social Change 18 (1990-1991): 743-76.

30. James W. Marquart, Sheldon Ekland-Olson, and Jonathan R. Sorensen. The Rope, the Chair, and the Needle: Capital Punishment in Texas, 1923-1990. Austin, Texas: University of Texas Press, 1994.

31. Dean Brock, Nigel Cohen, and Jonathan Sorensen. “Arbitrariness in the Imposition of Death Sentences in Texas: An Analysis of Four Counties by Offense Seriousness, Race of Victim, and Race of Offender.” American Journal of Criminal Law 28 (2000): 43-71. 
32. Scott Phillips. "Racial Disparities in the Capital of Capital Punishment.” Houston Law Review 45 (2008): 807-40.

33. Scott Phillips. "Legal Disparities in the Capital of Capital Punishment.” Journal of Criminal Law and Criminology 99 (2009): 717-56.

34. Scott Phillips. "Status Disparities in the Capital of Capital Punishment.” Law and Society Review 43 (2009): 807-37.

35. Scott Phillips, Laura Potter, and James E. Coverdill. "Disentangling Victim Gender and Capital Punishment: The Role of Media.” Feminist Criminology 7 (2012): 130-45.

36. Scott Phillips. "Continued Racial Disparities in the Capital of Capital Punishment: The Rosenthal Era.” Houston Law Review 50 (2012): 131-56.

37. Zant v. Stevens, 462 U.S. 862, decided 22 June 1983.

38. Pulley v. Harris, 465 U.S. 37, decided 23 January 1984.

39. McCleskey v. Kemp, 481 U.S. 279, decided 22 April 1987.

40. California v. Brown, 475 U.S. 1301, decided 27 March 1986.

41. Maynard v. Cartwright, 486 U.S. 365, decided 6 June 1988.

42. Walton v. Arizona, 497 U.S. 639, decided 27 June 1990.

43. Tuilaepa v. California, 512 U.S. 967, decided 30 June 1994.

44. Texas Capital Murder Statute. Available online: http://www.statutes.legis.state.tx.us/Docs/PE/ htm/PE.19.htm\#19.03 (accessed on 11 December 2013).

45. James R. Acker, and Charles S. Lanier. "Beyond Human Ability? The Rise and Fall of Death Penalty Legislation.” In America's Experiment with Capital Punishment: Reflections on the Past, Present, and Future of the Ultimate Penal Sanction. Edited by James R. Acker, Robert M. Bohm, and Charles S. Lanier. Durham, North Carolina: Carolina Academic Press, 2003, pp. 85-125.

46. George E. Dix, and John M. Schmolesky. "Capital Murder in Texas: Legislative Narrowing at the First Stage of Trial.” Texas Practice Series: Criminal Practice and Procedure 49, no.10 (2013): 1-3.

47. Texas Code of Criminal Procedure. Available online: http://www.statutes.legis.state.tx.us/Docs/ CR/htm/CR.37.htm (accessed on 18 December 2013).

48. Sam Kamin, and Justin Marceau. "The Facts about Ring v. Arizona and the Jury's Role in Capital Sentencing.” University of Pennsylvania Journal of Constitutional Law 13 (2010-2011): 529-86.

49. Senate Bill 60 Press Release. Available online: http://governor.state.tx.us/news/pressrelease/3603/ (accessed on 11 December 2013).

50. Texas Department of Criminal Justice. Available online: http:/www.tdcj.state.tx.us/death_row/ index.html (accessed on 11 December 2013).

51. Supplemental Homicide Reports. Available online: http://www.icpsr.umich.edu/icpsrweb/ NACJD/ (accessed on 11 December 2013).

52. Jeffrey Fagan, Franklin E. Zimring, and Amanda Geller. "Capital Punishment and Capital Murder: Market Share and the Deterrent Effects of the Death Penalty.” Texas Law Review 84 (2005-2006): 1804-67.

53. Officer Down Memorial Page. Available online: http://www.odmp.org/ (accessed on 11 December 2013).

54. Roper v. Simmons, 543 U.S. 551, decided 1 March 2005. 
55. David C. Baldus, George Woodworth, David Zuckerman, Neil Alan Weiner, and Catherine M. Gross. "Empirical Studies of Race and Geographic Discrimination in the Administration of the Death Penalty: A Primer on the Key Methodological Issues.” In The Future of America's Death Penalty. Edited by Charles S. Lanier, William J. Bowers, and James R. Acker. Durham, North Carolina: Carolina Academic Press, 2009, pp. 153-97.

56. Thomas H. Cohen, and Tracey Kyckelhahn. "Felony Defendants in Large Urban Counties, 2006." Bereau of Justice Statistics, 15 July 2010. Available online: http://www.bjs.gov/content/pub/ pdf/fdluc06.pdf (accessed on 11 December 2013).

57. Enmund v. Florida, 458 U.S. 782, decided 2 July 1982.

58. Tison v. Arizona, 481 U.S. 137, decided 21 April 1987.

59. Mark Cooney, and Callie Harbin Burt. "Less crime, more punishment.” American Journal of Sociology 114 (2008): 491-527.

60. Jefferson E. Holcomb, Marian R. Williams, and Stephen Demuth. "White Female Victims and Death Penalty Disparity Research.” Justice Quarterly 21 (2004): 877-902.

61. Marian R. Williams, Stephen Demuth, and Jefferson E. Holcomb. "Understanding the Influence of Victim Gender in Death Penalty Cases: The Importance of Victim Race, Sex-Related Victimization, and Jury Decision Making.” Criminology 45 (2007): 865-91.

62. Atkins v. Virginia, 536 U.S. 304, decided 20 June 2002.

63. Uniform Crime Reporting Statistics. Available online: http://www.ucrdatatool.gov/ (accessed on 16 January 2014).

(C) 2014 by the authors; licensee MDPI, Basel, Switzerland. This article is an open access article distributed under the terms and conditions of the Creative Commons Attribution license (http://creativecommons.org/licenses/by/3.0/). 